\title{
SPRÅKANVÄNDNING OCH SPRÅKVAL BLAND FINSK-NORSKA UNGDOMAR I OSLOOMRÅDET
}

\author{
Kristiina Lieri, Åbo universitet
}

\begin{abstract}
I artikeln studeras vilket språk (finska eller norska) de sex utvalda ungdomarna i åldern 17-22 år använder i tre olika domäner (hemdomänen, fritidsdomänen och massmediebruket) och hur språkvalet har förändrats under de åtta åren som var mellan de två olika undersökningstillfällena. Det belyses också faktorer som kan tänkas påverka dessa ungdomars språkval. Materialet består av intervjuer och enkät. Studiens ansats är sociolingvistisk.

Resultaten i denna undersökning bevisar norskans dominerande ställning i de undersökta ungdomarnas språkval. Undantag är hemdomänen där informanterna också talar finska. Det har skett en del förändringar i språkvalet, först och främst i hemdomänen. Språkvalet förklaras bäst av faktorerna socialt nätverk och förändring av språklig identitet. Resultaten visar vidare att några ungdomar är mer aktivt tvåspråkiga än de andra.
\end{abstract}

Nyckelord: domän, finska, norska, språkval, tvåspråkighet

\section{BAKGRUND OCH SYFTE MED STUDIEN}

Finländare utgör en liten minoritet i Norge trots att den finska invandringen till landet har pågått i flera hundra år (Niemi, 2010). Den nyare finska invandringen till Norge kan anses ha börjat på 70-talet. Då flyttade unga, ogifta kvinnor från de nordligaste delarna av Finland till Nordnorge där de fick arbete inom fiskindustrin. Många finskor stannande där efter att ha gift sig med norrmän (Anttonen, 2008). Finsk arbetskraft var också efterfrågad på skeppsvarv, oljeplattformar

Kirjoittajan yhteystiedot:

FM Kristiina Lieri

The School of Languages and Translation Studies,

University of Turku

kristiina.lieri@gmail.com

kristiina.s.lieri@utu.fi och inom byggnadsbranchen i södra Norge. Sedan mitten av 1990-talet har flyttningen till Norge kontinuerligt ökat. Förklaringen till detta är att arbetsmarknadssituationen har varit gynnsammare i Norge än i Finland. Rekordåret 1998 flyttade över 800 nya finländare till Norge och t.ex. antalet finska läkare och sjukskötare på norska sjukhus närapå fördubblades på kort tid. Årligen flyttar ca 400 finländare till Norge och majoriteten av dem är välutbildade (Anttonen, 2008; Lindgren, Eskeland \& Norman, 2003). Enligt officiella uppgifter publicerade av Statistisk sentralbyrå (SSB) bodde det per 1.1.2016 totalt 6362 finska medborgare i Norge (60 \% kvinnor respektive $40 \%$ män). Av dessa bodde 2070 (32,5\%) i Oslo och Akershus (Stor-Osloområdet), 1369 (21,5\%) i Nordnorge (Finnmark och Troms) och 2923 (46\%) spridda över andra delar av landet. Majoriten av de finländare som idag bor i Norge är i den bästa arbetsföra åldern, mellan 20-66 år (77 \%). 


\subsection{Syfte och frägeställningar}

Språkval och språkanvändningsmönster har globalt sett varit vanliga forskningsområden (se t.ex. Auer \& Li Wei, 2007; Baker, 2001; Romaine, 1995) och det finns gott om sådana undersökningar i flerspråkiga samhällen. Många av de nordiska studierna behandlar finska informanter i Sverige, och utöver barnens språkval berörs också familjens språkvanor i kontakter med omgivningen (se t.ex. Boyd, 1985; Boyd, Holmen \& Jørgensen, 1994; Janulf, 1998; Tuomela, 2001). I denna artikel undersöker jag utvecklingen i språkanvändning och språkval hos sex finsk-norska ungdomar i Osloområdet vilkas föräldrar i vuxen ålder har flyttat från sitt hemland, Finland, till ett annat land, Norge. Språkval har inte tidigare undersökts bland norsk-finska barn och ungdomar förutom i Nordnorge (se Hjulstad Junttila \& Andersson, 1994; Komeros, 2009; Niiranen, 2008). Min studie bidrar till att synliggöra språkvalet hos tvåspråkiga ungdomar i Osloområdet. Informanterna har vuxit upp med två språk i barndomen. De har lärt sig finska som forstaspråk (S1) och norska som andraspråk (S2). Med förstaspråk avses det språk som en person först lär sig tala som barn (Romaine, 1995, s. 19). När personen lär sig ytterligare ett språk efter att förstaspråket har etablerats talas det om andraspråkstillägnande (Sundman, 1999, s. 43). Ungdomarna i denna undersökning kommer från helfinska familjer till skillnad från barn och ungdomar i de nordnorska studierna där den ena föräldern, oftast modern, är finsk.

Undersökningen syftar till att besvara följande frågor: i) Vilka språk använder ungdomarna inom hemdomänen, fritidsdomänen och i massmediebruket? ii) Hur har språkvalet förändrats under de åtta år undersökningen omfattar? och iii) Vilka faktorer kan tänkas påverka dessa ungdomars språkval? Informanternas språkval kontrasteras mot de mönster som framkommit i tidigare studier hos finskspråkiga samt andra minoritetsspråkiga barn och ungdomar i Norge (Hjulstad Junttila \& Anderson, 1994; Komeros, 2009, Kulbrandstad, 1997; Niiranen, 2008; Svendsen, 2005) och Sverige (Namei, 2012; Straszer, 2011). Studien har ett longitudinellt grepp, vilket gör det möjligt att påvisa förändringar som skett. Longitudinella studier har mig veterligen inte genomförts tidigare bland norsk-finska barn och ungdomar. Eftersom denna studie bygger på ett begränsat antal informanter, kan den inte ge underlag för några generella slutsatser om språkval bland finsk-norska ungdomar. Resultaten kan dock påvisa en del tendenser i språkval hos finska ungdomar i Osloområdet.

Artikeln inleds med att definiera de begrepp som används i studien. Därefter följer en översikt över relevant forskning om språkval hos finska barn och ungdomar i Norge och Sverige samt andra invandrargrupper $i$ Norge. Sedan presenteras undersökningens teoretiska utgångspunkter. Därefter följer ett avsnitt där material och metod för den empiriska studien behandlas. I resultatavsnittet redogörs för en kvalitativ analys av intervjun och enkäten samt vilka faktorer som inverkar på språkbruket hos de utvalda informanterna. Artikelns avslutas med en sammanfattande diskussion om studiens resultat.

\section{TIDIGARE FORSKNING OM SPRÅKVAL OCH SPRÅKANVÄNDNINGSMÖNSTER}

Som konstaterats har språkval och språkanvändningsmönster varit föremål för åtskilliga studier (se Auer \& Li Wei, 2007; Baker, 2001; Romaine, 1995). Många av de tidigare studierna berör språkval i språksamhällen, där det ena språket är majoritetsspråket, det andra minoritetsspråket. Ett majoritetsspråk är det språk som talas av den dominerande 
befolkningsgruppen i ett samhälle. Det är i regel landets eller områdets officiella språk (Mæhlum, 2007, s. 127). Ett minoritetsspråk är ett språk som talas av en minoritetsgrupp i ett land och som antingen kan vara ett nationellt minoritetsspråk eller ett invandrarspråk. Minoritetsspråkets status är beroende av lagstiftningen i majoritetssamhället (Fredriksen, 1997, s. 41).

Tvåspråkighet är ett mångfacetterat fenomen som uppvisar varierande drag hos olika personer och i olika samhällen (Caldas, 2006, s. 1). Tvåspråkiga individer tillägnar sig och använder sina språk i olika språkliga domäner, där syftet för interaktionen varierar. Med domän avses inom språkforskningen en typ av sammanhang där individerna använder ett visst språk. Typiska domäner är hem, skola, fritid och media (Romaine 1995, s. 30-31). Språkval är beslutet att använda ett visst språk i en viss situation, domän eller kontext (Straszer, 2011, s. 23). En tvåspråkig individ gör hela tiden val mellan sina två språk och språkvalet hos en och samma individ varierar tidvis (Grosjean, 1982, s. 238). Med språkanvändninsgmönster avses med vilka personer och i vilka situationer samt i vilken omfattning individen kommer i kontakt med sitt $\mathrm{S} 1$ och S2 (Tuomela, 2001, s. 85). Ett socialt nätverk består av familjemedlemmar, släktingar, vänner och skolkamrater som är i frekvent eller nära kontakt med varandra (Milroy \& Gordon, 2003, s. 117).

I det följande redogörs för norska och svenska undersökningar relaterade till språkval och språkanvändningsmönster hos minoritetsgrupper i majoritetssamhällen. Språkval hos finsktalande barn och ungdomar i Norge har endast undersökts i några få studier (Hjulstad Junttila \& Andersson, 1994; Komeros, 2009; Niiranen, 2008). I samtliga studier redogjordes för språkval av informanter i Nordnorge (Finnmark och Troms). Hjulstad Junttila och Andersson (1994) inhämtade upplysningar om barnens språkval genom intervjuer med föräldrarna. Genomsnittsåldern för de sammanlagt 32 barnen var 10,7 år vid intervjutillfället. Hjulstad Junttila och Andersson (1994) fann att informanterna tidigt kom i kontakt med majoritetsspråket och använde relativt mycket norska även i hemdomänen. De hade få regelbundna kontakter med andra finsktalande barn. Detta var en tydlig skillnad jämfört med t.ex. finnar i Göteborg, som använde mer finska inom olika domäner och hade betydligt mer kontakt med andra finskspråkiga (Boyd m. fl., 1994).

Niiranen (2008) samlade in information om språkvalet bland tio informanter i åldern 12-15 år i Finnmark. Resultaten i hennes doktorsavhandling visade att de fem tvåspråkiga informanterna i studien, som alla hade en finsktalande mor, använde finska inom hemdomänen, skoldomänen, fritidsdomänen och i massmediebruket, medan norskan i övrigt var det dominerande språket. De fem övriga informanterna hade inte någon finskspråkig förälder utan studerade finska som S2. Undersökningen visade vidare att bruket av finskan minskade i två tvåspråkiga familjer under årens lopp. Resultaten i både Hjulstad Junttilas och Anderssons samt Niiranens studier slår fast att de finsk-norska informanterna hade mycket kontakt med majoritetsspråkiga i det sociala nätverket. Barn och ungdomar hade få finsktalande vänner och skolkamrater i uppväxtmiljön, vilket berodde på gruppens begränsade storlek och det geografiska läget i Nordnorge.

Komeros (2009) kartlade alla nationaliteter bosatta i Sør-Varanger kommun och studerade vilka språk dessa talade samt deras språkval i tre domäner (dagvården, skolan och hemmet). Hon intervjuade även fyra familjer där minst en förälder var finsk. Ungdomarna var i åldern 15-22 år. Två av familjerna använde finska aktivt och hade kontakt med släkt och vänner i Finland. I de två andra familjerna däremot talades inte finska och ungdomarna 
hade inte heller någon kontakt med sina släktingar i Finland. Dessa ungdomars kunskaper i finska var så svaga att de inte kunde kommunicera på finska. De var besvikna över att fadern/ modern inte hade lärt dem finska.

Heikkola (2005) undersökte språkvalet hos tio informanter i åldern 22-67 i Oslo. Hon fokuserade på kodväxling och attityder gentemot Finland, finskheten och det finska språket samt Norge, norrmän och det norska språket. Av Heikkolas resultat framgår att finskheten var ytterst viktig för informanterna även om några informanter hade bott länge i Norge. Alla informanter identifierade sig som finländare, men de var välintegrerade i det norska samhället. Finländarna hade i stort sett en positiv inställning till Norge, norrmän och det norska språket. Ju längre informanterna hade bott i Norge, desto mer använde de norska i vardagslivet och kodväxlade mer.

I Kulbrandstads (1997) rapport om språkanvändningsmönster och språkfärdigheter hos 12 iransk-norska och vietnamesisk-norska elever i årskurs 3 och 8 framkom att informanterna dagligen använde både sitt $S 1$ (persiska/ vietnamesiska) och norska inom olika domäner medan S1 dominerade hemma. Språkanvändningsmönstret förändrades under den tid de tillbringade i Norge. Ju längre informanterna hade bott i landet, desto mer använde de S2 inom olika domäner. Resultaten visade vidare att flickorna använde mer norska än pojkarna och informanterna hade många landsmän i det sociala nätverket (särskilt vietnameser). Svendsen (2005) fokuserade på språkval (norska, engelska och filippinska språk) hos fem norsk-filippinska informanter i åldern 8-9 år i Osloområdet. Hon fann att språkanvändningsmönstret var ytterst komplext. Föräldrarnas olika förstaspråk hade en stark ställning inom hemdomänen och föräldrarna överförde målmedvetet sitt/sina språk till nästa generation. Norsk-filippinarna hade också mycket kontakt med sina lands- män inom olika aktiviteter. I både Kulbrandstads (1997) och Svendsens (2005) studier hade informanterna mer kontakt med sin egen minoritetsgrupp och de använde minoritetsspråket mer jämfört med informanterna i Hjulstad Junttilas och Anderssons (1994) samt Niiranens (2008) undersökningar.

Studier om sverigefinnar har ofta berört olika undervisningsmodeller och i detta sammanhang har även språkval tagits upp. I Janulfs (1998) longitudinella studie om språkkunskaper och språkanvändning hos andra generationens sverigefinnar (41 informanter) $i$ Botby kom det fram att f.d. elever i svensk klass hade övergått till att tala svenska med sina föräldrar och syskon i större utsträckning än de f.d. eleverna i finsk klass. Tuomela (2001) studerade tvåspråkig utveckling hos 108 elever $\mathrm{i}$ årskurserna 3, 6 och $9 \mathrm{i}$ tre olika undervisningsmodeller. Han fann att informanterna i en svensk klass i allmänhet använde mer svenska med föräldrarna och syskonen än eleverna i tvåspråkiga klasser och i tvåspråkig friskola. De två sistnämnda grupperna använde också mer finska i skolan och på fritiden. I Janulfs (1998) och Tuomelas (2001) studier framkom att undervisningsmodellerna påverkade språkanvändningsmönstret och att undervisningen på minoritetsspråket hade en positiv inverkan på bruket av $S 2$.

I detta avsnitt har jag berört några relevanta studier gällande tvåspråkiga barn och ungdomar i Norge och sverigefinnar i Sverige. Den allmänna slutsatsen av dessa undersökningar är att barn och ungdomar använder båda språken, men användningen varierar inom olika domäner. Informanterna använder huvudsakligen minoritetsspråket inom hemdomänen medan majoritetsspråket dominerar inom skoldomänen, fritidsdomänen och i massmediebruket. Studierna visar att vistelsetiden, gruppstorleken, kontakterna med andra i samma språkgrupp samt undervisningen är de faktorer som inverkar på språkvalet. Detta 
berörs noggrannare i följande avsnitt där jag presenterar faktorer som förefaller centrala för den empiriska analysen av mitt material.

\section{TEORETISKA}

\section{UTGÅNGSPUNKTER}

En tvåspråkig persons språkval påverkas av mångfaldiga individuella och sociolingvistiska faktorer i olika kommunikationssituationer. Nedan redogörs först för faktorer som har med den yttre situationen att göra (omgivning, plats, domän och samtalsämne). Sedan behandlar jag individuella faktorer och identitet. Slutligen tar jag upp den sociala situationen, som omfattar språkens status, omgivningens tryck och attityder.

För tvåspråkiga personer är det typiskt att välja språk efter samtalspartner (Grosjean, 1982, s. 128). Språkvalet beror på släktskapsförhållanden (förälder-barn, hustru-man) och närhet till personen (Berglund, 2008, s. 61). Man använder ofta sitt S1 med familjemedlemmar och nära vänner, särskilt när man diskuterar något intimt (Grosjean, 1982, s. 137). Även situation, dvs. omgivning, plats och närvaron av enspråkiga talare är avgörande för språkvalet. När barn och ungdomar är på besök hos släktingar i föräldrarnas hemland väljer de ett visst språk (Niiranen, 2008, s. 40; Straszer, 2011, s. 166). Aktiviteter (t.ex. måltid, lek och högläsning) och olika domäner (skola, fritid, medier) påverkar i stor utsträckning språkvalet (Berglund, 2008, s. 180). En person väljer olika språk i olika domäner, t.ex. ett språk i skolan eller på fritiden och ett annat hemma. Ämnet, dvs. innehållet i saksammanhanget (skola, sport, nationella fester) och typen av ordförråd har också en avgörande roll i språkvalet. Barn och ungdomar brukar ofta tala om skolrelaterade ämnen på majoritetsspråket medan familjeinterna ting ofta diskuteras på minoritetsspråket (Namei, 2012, s. 206; Sundman, 1999, s. 49).
Även deltagarnas lingvistiska historia (vistelsetiden i landet och det först inlärda språket), språkliga preferens och språkkunskaper påverkar språkvalet (Kopeliovich, 2013, s. 260-261; Namei, 2012, s. 57, 184). Med tilltagande ålder brukar barn och ungdomar ha mer kontakt med jämnåriga majoritetsspråkiga ungdomar och de börjar använda majoritetsspråket i högre grad (Kopeliovich, 2013; Kulbrandstad, 1997; Niiranen, 2008). Samtalsparterna kan föredra att tala det ena språket tillsammans även om de behärskar båda språken (Caldas, 2006, s. 108). En tvåspråkig individ har ofta begränsade möjligheter att använda sitt $\mathrm{S} 1$, om det är ett minoritetsspråk i samhället (Mæhlum, 2007, s. 127; Tandefelt, 1988, s. 17-18). S2/majoritetsspråket blir då det dominerande språket samtidigt som kompetensen i $S 1$ hos individen ifråga riskerar att gradvis försämras på grund av minskad användning (Sundman, 1999, s. 46; Tandefelt, 1988, s. 18). Detta leder till att vederbörande i större utsträckning använder majoritetsspråket även i situationer där han/hon kunde tala minoritetsspråket (Boyd m.fl., 1994). Även deltagarnas kön påverkar språkvalet. Kvinnor och flickor tycks oftare överge sitt $S 1$ än män och pojkar (Namei, 2012; Pavlenko, 2005).

Etnisk identitet betyder att en person anser sig tillhöra en folkgrupp och sympatiserar med dess kulturella normer och uttryck (Benjamin, 2014, s. 76-78; Lanza \& Svendsen, 2007, s. 286; Liebkind, 2010, s. 18). Individerna är i allmänhet motiverade att tillhöra en grupp som värderas positivt och har hög status (Henning-Lindblom, 2012, s. 76). Med språklig identitet avses att en person identifierar sig med en bestämd språklig grupp. Språklig identitet rör sig om attityder och värderingar gentemot $S 1$ och S2 samt språkunskaper (Iskanius, 2006, s. 43; Virta, 1994, s. 24). Hur en tvåspråkig människa upplever att hon behandlas som en tvåspråkig person av enspråkiga och tvåspråkiga i omgiv- 
ningen påverkar hennes identitetsutveckling (Straszer, 2011, s. 64-65). Identiteten betraktas inte som fixerad, enhetlig och självständig, utan förändras efter ålder, livssituation och livserfarenhet (Aalto, 2015; s. 6; Haglund, 2004, s. 376; Hall, 1999, s. 203). Identiteten är således inte något som individen bär med sig och som finns, utan något som skapas i mötet med andra (Otterup, 2005, s. 28; se också Fogle, 2013).

Den sociala situationen såsom språkens status i det omgivande samhället (t.ex. finskan i Norge) och omgivningens tryck är centrala faktorer för språkvalet (Spolsky, 2009, s. 90; se också Forsman, 2015, s. 52-56). Majoritetssamhällets syn på minoritetsspråk påverkar intresset att använda språket. Om minoritetsspråket har låg status är det mer sannolikt att man använder det språk som har högre status (Baier, 2007, s. 145-148, Otterup, 2005, s. 16). Många ungdomar med invandrarbakgrund vill gärna identifiera sig med majoritetsungdomar för att höja sin status och därför väljer de att tala majoritetsspråket (Mæhlum, 2007). Även föräldrar med minoritetsbakgrund kan börja tala majoritetsspråket med sina barn av samma orsak (Weckström, 2008). Barn och ungdomar är mycket känsliga för omgivningens åsikter om vilket språk de skall använda i olika situationer (Baker, 2007, s. 7-9; Caldas 2006, s. 114-115). Enligt Lainio (2006) kan en avvisande eller oförstående attityd till användningen av $S 1$ leda till att barnet och ungdomen börjar skämmas för språket och därmed inte vill använda det. Det är svårt för dem att utveckla positiva attityder gentemot tvåspråkighet om de upplever att deras språk och kulturella grupp inte uppskattas av medlemmarna i majoritetsgruppen (Lanza, 2007, s. 49-52). På det individuella planet har attityden till ett språk betydelse för att individen ska vilja bevara och utveckla sin färdighet i båda språken (Janulf, 1998, s. 175; Pavlenko,
2005, s. 31-32). Institutionell autonomi, dvs. i vilken utsträckning minoriteten har tillgång till egna institutioner som skola, kyrka, föreningar och tidningar spelar också en viktig roll för det språkanvändningsmönster talarna av minoritetsspråket väljer (Kovács, 2004; Namei, 2012; Tandefelt, 1988).

\section{MATERIAL OCH METOD}

Som konstaterats tidigare är syftet med denna artikel att beskriva språkanvändningen och språkvalet hos sex finsk-norska barn och ungdomar med finskspråkiga föräldrar bosatta i Osloområdet, studera utvecklingen mellan de två materialinsamlingstillfällena samt analysera faktorer som kan tänkas ha en inverkan på dessa barn och ungdomars språkval. I detta avsnitt beskriver jag först informanterna. Vidare presenterar jag det empiriska materialet för undersökningen, först intervjuerna och sedan enkäten.

\subsection{Informanterna}

Den viktigaste grunden för urvalet av informanterna var att båda föräldrarna hade invandrat till Norge i vuxen ålder och hade finska som S1 (men besitter även färdigheter i norska). Bakgrundsinformation om informanterna ges i tabell 1 . Vid första undersökningstillfället hade två familjer bott $\mathrm{i}$ Norge i ca 20 år och de två andra i ca 6 år. Två familjer hade flyttat till Norge på grund av bättre arbetsmöjligheter, en familj blev sänd av arbetsgivaren och den färde hade lust att uppleva något nytt. Familjerna hade för avsikt att stanna i Norge. Samtliga familjer bodde i samma kommun där de flesta grannarna var etniska norrmän. 
Tabell 1. Bakgrundsinformation om informanterna.

\begin{tabular}{|l|l|l|l|l|l|l|}
\hline Informant & $\begin{array}{l}\text { Kön, plats i } \\
\text { syskonskara }\end{array}$ & $\begin{array}{l}\text { Födelse- } \\
\text { år }\end{array}$ & $\begin{array}{l}\text { Födelse- } \\
\text { land }\end{array}$ & $\begin{array}{l}\text { Ålder vid } \\
\text { flyttning } \\
\text { till Norge }\end{array}$ & $\begin{array}{l}\text { Ålder vid } \\
\text { första } \\
\text { intervjutillfället }\end{array}$ & $\begin{array}{l}\text { Bott i Norge } \\
\text { vid andra } \\
\text { intervjutillfället }\end{array}$ \\
\hline 1 & flicka, yngst & 1990 & Norge & & 14 år & hela livet \\
\hline 2 & flicka, äldst & 1991 & Finland & 7 år & 13 år & 15 år \\
\hline 3 & flicka, äldst & 1993 & Norge & & 11 år & hela livet \\
\hline 4 & flicka, yngst & 1994 & Finland & 4 år & 10 år & 15 år \\
\hline 5 & pojke, äldst & 1993 & Finland & 5 år & 11 år & 15 år \\
\hline 6 & pojke, yngst & 1995 & Norge & & 9 ar & hela livet \\
\hline
\end{tabular}

Informanterna 3 och 6 samt 4 och 5 är syskonpar. Det kan vara givande att jämföra barn i samma familj. Trots att syskonen har likartad social situation, kan det tillföra en annan dimension. Tre av de sex informanterna är födda i Norge och har tidigt lärt sig två språk. De har haft kontakt med norsktalande barn sedan sina första barndomsår. Tre informanter är födda i Finland. Två av dessa flyttade till Norge i förskoleåldern och en började i norsk skola mitt under det andra skolåret (första klassen hade avverkats i Finland). Alla de sex informanterna var i skolåldern (9-14 år) när undersökningen började och de angav finska som sitt S1.

Sedan 1997 har eleverna i de två nordligaste länen i Norge kunnat studera finska som andraspråk och i hela landet är det möjligt (i princip) att studera finska som valbart språk på högstadiet och i gymnasiet. Utanför Nordnorge har de finska eleverna möjlighet att få undervisning på finska (t.ex. stödundervisning och tvåspråklig ämnesundervisning) om eleven har ett särskilt behov av sådan undervisning. Finska som modersmål undervisas idag först och främst för barn som har flyttat från Finland och inte har kunskaper i norska (Niiranen, 2011). Samtliga informanter hade begränsade möjligheter att få undervisning i och på finska under sin skolgång. Informant
1 och 3 deltog i modersmålsundervisning i två år medan informant 6 inte fick någon undervisning i finska alls. Detta beror på att kommunen kunde erbjuda mindre undervisning på barnens modersmål p.g.a strängare regler efter läroplansreformen 1997. Informanterna 2, 4 och 5 deltog i någon form av finskundervisning i ca två-fyra år. I Oslo finns det också en finsk lördagsskola (Suomi-koulu) där man kan få finskundervisning ett par timmar varannan lördag.

\subsection{Intervjuerna år 2004}

Det empiriska materialet består av en intervju och en skriftlig enkät. Data insamlades i två omgångar. Datainsamlingen började med en intervju våren 2004 då barnen var i åldern 9-14 år. Informanterna fyllde i enkäten åtta år senare, nämligen hösten 2012. Jag tar först upp intervjuerna och därefter enkäten (4.3).

Jag använde halvstrukturerade intervjuer med informanterna (Kvale \& Brinkmann, 2009, s. 143). Jag följde ett skriftligt schema som jag hade utarbetat i form av en intervjuguide. I guiden stod alla frågor som jag skulle ställa i en bestämd ordning. Målet med metoden var att jag fick samma data om alla informanterna. Materialet från de olika intervjuerna blev på det sättet jämförbart (Milroy \& 
Gordon, 2003). Intervjuerna inspelades inte utan jag nöjde mig med att anteckna stickord under intervjun, renskrev anteckningarna efter varje besök och överförde materialet till datorn. Här föreligger ett metodologiskt problem då man kan glömma bort något väsentligt som blev sagt. Jag hade dock möjlighet att ta kontakt med informanterna på nytt om något var oklart.

Intervjun gjordes hemma hos barnet. Detta var den första kontakten mellan barnet och intervjuaren. Syftet med intervjun var att kartlägga barnets språkval i tre olika domäner. Informanten valde själv på vilket språk, norska eller finska, han/hon ville svara på frågorna. Barnet tillfrågades om dess språkval hemma med föräldrarna och syskonen samt sociala nätverk: fritidsaktiviteter, hur ofta barnet var tillsammans med norsktalande och finsktalande barn och ungdomar och vilket språk barnet talade med sina vänner (t.ex. Vilket språk talar du oftast med dina vänner? Talar du någon gång finska?). En del frågor hade att göra med skolan: vilka språk barnet använde på lektionerna och på rasterna. Barnet fick även berätta vilket/vilka språk han/ hon använde vid fritidsläsning (serietidningar och böcker) och till privat skrivande (vykort och meddelanden hemma). Barnet fick också berätta på vilket språk han/hon lyssnade på musik, såg på TV/DVD eller spelade dataspel. Barnet uppmanades vidare att bedöma sina färdigheter i både finska och norska. Det frågades också om barnets syn på sin identitet (Känner du dig finsk eller norsk eller tvåkulturell?). Modern var med i samma intervjusituation och hon tillfrågades om diverse övriga uppgifter rörande barnet (t.ex. om barnet fått undervisning i och på finska och på vilket språk barnet lärde sig skriva och läsa). Vid intervjutillfället svarade modern dessutom på frågor om vilket språk hon önskade att barnet helst skulle använda hemma och hur viktigt det var att barnet bevarade det finska språ- ket. Modern tillfrågades om föräldrarnas socioekonomiska bakgrund samt invandringsbakgrund, som här syftar på vistelsetiden och avsikten att förbli i landet.

\subsection{Enkäterna år 2012}

De skriftliga enkäterna ifylldes av ungdomarna hösten 2012 (informanterna var då i 1722-års åldern). Enkäten var skriven på norska då intervjun åtta år tidigare visade att några informanter hade problem att förstå finska. Enkäten sändes hem till informanterna och den returnerades inom en månad. Frågorna i enkäten indelades i två delar (se t.ex. Dörnyei \& Taguchi, 2010). Frågorna i del ett handlade om informanternas språkbruk inom hemdomänen (vilket språk informanten använde med föräldrarna och syskonen hemma) och inom fritidsdomänen (språkbruket utanför hemmet). Frågor som gällde informanternas sociala nätverk berördes, såsom kontakten med finsk- respektive norsktalande personer. Även informanternas massmediebruk behandlades här. Frågorna i enkäten var dock inte helt identiska med frågorna i intervjun eftersom barnen vid intervjutillfället inte hade tillgång till mobiltelefon eller använde sociala medier. När informanterna besvarade frågorna i enkäten var SMS, mejl och sociala medier en viktig del av deras massmediebruk. Informanterna fick berätta vilket/vilka språk de använde när de läste på fritiden, vid privat skrivande, som t.ex. korta meddelanden hemma (minneslappar och inköpslistor) samt vid användning av elektronisk kommunikation (SMS, mejl och social media). Var och en fick också berätta på vilket språk de lyssnade på radio och såg på TV/DVD. I enkätfrågorna som gällde språkval inom de tre domänerna ombads informanterna att välja hur ofta han/ hon använde sina språk i olika domäner. Frågorna bestod av flervalsfrågor som t.ex. löd: Hur ofta väljer du en film på finska när du ser 
på $D V D$ ? och svarsalternativen: a) alltid, b) oftast, c) då och då d) aldrig.

I del två berördes frågor om informanternas attityder till sina två språk, deras språkliga och etniska identitet samt känslan av samhörighet med Norge och Finland. Dessa är faktorer som också kan tänkas påverka språkvalet (Allardt Ljunggren, 2008; Baier, 2007). Informanterna ombads att besvara öppna frågor om huruvida de kände sig som norska eller finska eller ansåg sig ha multipel identitet, vilka språk de själva uppfattade som viktigast samt vilket språk de skulle tala med sina barn. De tillfrågades dessutom om resor till Finland och om finska traditioner som var viktiga för dem (t.ex. Hur ofta brukar du resa till Finland?). Informanterna fick ta ställning till vissa påståenden och därefter ange huruvida påståendena överensstämde med deras egna erfarenheter. Den 4-gradiga skalan från 'stämmer helt, stämmer delvis, stämmer inte alls' och vet inte var med. Informanterna ombads att berätta hur de själva och norrmännen förhöll sig till finnar och det finska språket samt ta ställning till tvåspråkighet som tillgång. Vidare handlade påståendena om huruvida de kunde tänka sig att studera, flytta till och bo några år i Finland (t.ex. Jag kan tänka mig att studera i Finland).

\subsection{Analysmetoden}

Intervjumaterialet analyserades kvalitativt för varje individ separat i syfte att beskriva informanternas språkval och språkbruk inom de tre olika domänerna. Dessutom fick jag in data om deras bakgrund som användes för att analysera de faktorer som förväntades påverka språkvalet. På basis av intervjuerna gjorde jag upp ett slags "språkprofil" för informanterna i ett textbehandlingsprogram. I varje "språkprofil" beskrevs t.ex. informantens bakgrund, språkval i de tre domänerna, etniska och språkliga identitet samt undervis- ning i och på finska. Svaren i enkätmaterialet analyserade jag först kvantitativt genom att mata in data i en excel-tabell. I flervalsfrågor (del 1) bedömde jag språkvalet på varje punkt. T.ex. på frågan Hur ofta väljer du en film på finska/norska när du serpå $D V D$ ? valde informanten mellan svarsalternativen: a) alltid, b) oftast, c) då och då d) aldrig. I analysen skrev jag att informant 1 ser på DVD-filmer "bara norska", "mest norska", "lika mycket norska och finska", "mest finska" eller "bara finska". Därefter skrev jag en ny språkprofil för varje ungdom där jag beskrev språkvalet i de tre domänerna samt data som framkom av enkätens öppna frågor och påståenden, bl.a. etnisk och språklig identitet. Jämförelsen mellan de två undersökningstillfällena har jag gjort på basis av språkprofilerna. De förändringar som skett under de åtta åren beskriver jag på gruppnivå, d.v.s. för gruppen som helhet.

\section{RESULTAT}

Min disposition av redogörelsen för analysresultaten bygger på de tre domänerna (hemdomän, fritidsdomän och massmediebruk). Först berörs språkvalet i familjen efterföljt av språkvalen i förhållande till hobbyer och med vänner på fritiden och slutligen språkvalet $\mathrm{i}$ samband med massmediebruket. På grund av att detta är en longitudinell undersökning jämförs ungdomarnas språkval vid två olika tidpunkter.

\subsection{Ungdomarnas språkval i bemdomänen (inkl. släktingar)}

Informanterna tillfrågades om språkvalen i sitt umgänge med familjemedlemmarna vid det första intervjutillfället och i enkäten åtta år senare. Först redogör jag för språkvalen inom hemdomänen baserade på resultaten $\mathrm{i}$ intervjun (tabell 2) och därefter på resultaten $\mathrm{i}$ ungdomarnas självrapportering. 
Tabell 2. Språkval inom hemdomänen (inkl. släktingar) på basis av intervju år 2004. Språket som barnet använder mest nämns först.

\begin{tabular}{|l|l|l|l|l|l|}
\hline Informant & Född i & $\begin{array}{l}\text { Språkval med } \\
\text { fadern }\end{array}$ & $\begin{array}{l}\text { Språkval med } \\
\text { modern }\end{array}$ & $\begin{array}{l}\text { Språkval med } \\
\text { syskonen }\end{array}$ & $\begin{array}{l}\text { Språkval med } \\
\text { släktingar }\end{array}$ \\
\hline 1 & Norge & finska & finska & finska/norska & finska \\
\hline 2 & Finland & finska & finska/norska & finska/norska & finska \\
\hline 3 & Norge & finska & finska/norska & norska & finska/norska \\
\hline 4 & Finland & finska & finska/norska & finska/norska & finska \\
\hline 5 & Finland & finska & finska/norska & finska/norska & finska \\
\hline 6 & Norge & finska & norska & norska & finska/norska \\
\hline
\end{tabular}

Av tabell 2 framgår att barnen använde båda språken inom familjedomänen. Alla barnen talade enbart finska med fadern medan flera talade både finska och norska med modern. Enligt tidigare forskning påverkar föräldrarnas eget språkval tydligt vilket språk barnet väljer. Om föräldrarna inte konsekvent talar sitt S1 med barnen, byter de lätt till majoritetsspråket som också blir deras dominerande språk (de Houwer, 2007, s. 412). Särskilt faderns roll har visat sig vara viktig för minoritetsspråkets bevarande (Romaine, 1995, s. 187). Språkvalet med modern är intressant. Trots att båda föräldrarna är finsktalande och de sinsemellan talar finska, valde flera mödrar att tala norska med sina barn (se också Komeros, 2009). Informant 6 (född i Norge, det yngsta barnet i familjen, modern hade bott i Norge i över 20 år) talade endast norska med sin mor. Mödrarna till informanterna 2, 4 och 5 började tala norska med barnen eftersom de önskade att barnen skulle lära sig norska och integreras snabbare i det nya hemlandet (jfr Baker, 2007, s. 8, s. 23). Det framkom i intervjuerna att mödrarna önskade att barnen helst skulle tala finska i hemmiljön, men likväl talade de ofta norska med barnen. Detta kan bero på att samtliga mödrar använde norska på jobbet och hade relativt goda kunskaper i norska medan fäderna oftast talade engelska och norskkunskaperna inte var lika goda. Mitt resultat överensstämmer med tidigare studier i fråga om det faktum att majoriteten av barn och ungdomar med utländsk bakgrund talar såväl majoritetsspråket som minoritetsspråket med modern men i huvudsak minoritetsspråket med fadern (Barron-Hauwaert, 2011; Namei, 2012; Svendsen, 2005). Vidare bekräftar resultaten vikten av att föräldrarna konsekvent talar sitt S1med barnen, i annat fall byter barnen lätt till $S 2$.

Alla barnen i denna studie har ett syskon. Informanterna 3 och 6 samt 4 och 5 är syskonpar. Syskonen talade sinsemellan både finska och norska förutom informanterna 3 och 6 som enbart talade norska. Informanterna 2 , 4 och 5 talade mest finska med sina syskon vid intervjutillfället. En förklaring till detta kan vara att de bodde sina första år i Finland och var vana vid att tala finska sinsemellan. De tre barnen födda i Norge (informanterna 1, 3 och 6) stannade hemma med modern de första tre åren men de deltog i organiserade aktiviteter med norsktalande barn ett par gånger i veckan. Samtliga barn talade mest finska med modern under denna period. Mödrarna berättade att språkvalet mellan syskonen började förändras när det äldsta barnet började skolan och fick norsktalande skolkompisar på besök i hemmet. Norskan blev således 
alltmer dominerande i vardagslivet (se också Barron-Hauwaert, 2011; Spolsky, 2009). Hemdomänen är ytterst viktig under de första åren medan de andra domänernas betydelse blir viktigare när barnen blir äldre vilket också påverkar språkvalet (Baker, 2007).

I intervjun tillfrågades modern och barnet också vilket språk det talade med släktingarna. På familjebesök i Finland talade informanterna enbart finska med de enspråkigt finsktalande släktingarna (far- och morföräldrar, fastrar, mostrar och kusiner). När barnen var små, reste familjerna till Finland ett par gånger om året och några barn tillbringade längre tidsperioder hos far- och morföräldrarna om sommaren. Några hade också kusiner i samma ålder och de hade mycket kontakt med varandra under sommarlovet. Kontakterna med föräldrarnas fosterland och vistelser där verkar ha positiv inverkan på bruket av minoritetsspråket vilket också framgått av tidigare studier (se t.ex. Caldas, 2006, s. 5759; Niiranen, 2008, s. 30; Rydenvald, 2014, s. 41-44; Straszer, 2011, s. 226). Bara två informanter (3 och 6) hade finsktalande släktingar i Norge och de talade båda språken med dem.

Tidigare studier har visat att föräldrarna i tvåspråkiga familjer har svårigheter att få sina barn att spontant tala minoritetsspråket om majoritetsspråket är ett av språken i familjen (se t.ex. Niiranen, 2008; Komeros, 2009;
Barron-Hauwaert, 2011). Detsamma gäller också familjer där båda föräldrarna talar samma minoritetsspråk som S1 (Svendsen, 2005). De finska mödrarna i denna studie vittnar om att barnen under vissa perioder inte velat tala finska och verkat irriterade när föräldrarna ställt krav på dem att tala hemspråket. Om båda föräldrarna är minoritetsspråkstalare tenderar det att stärka språkbevarandet (Boyd m.fl., 1994, György-Ullholm, 2010). Föräldrarnas medvetna språkplanering är dock viktigt för språkbevarandet (Caldas, 2006; de Houwer, 2007; Namei, 2012). Det gäller inte bara i barndomen utan också i ungdomen (Baker, 2007, s. 9). Det verkar som om familjerna i denna studie inte hade beslutat sig för en klar språkstrategi för att utveckla tvåspråkigheten hos barnen. Det bör dock påpekas att familjespråkpolicy sällan är statisk utan förändras över tid och ständigt omförhandlas och påverkas av yttre och inre omständigheter (Palviainen, Lehtonen \& Valli, 2012, s. 6). Särskilt mödrarnas språkanvändning pekar på detta (jfr Barron-Hauwaert, 2011, s. 9-11).

Samma frågor om språkvalet inom familjedomänen ställdes till informanterna i enkäten åtta år senare (självrapportering). I tabell 3 redogörs för vilket språk ungdomarna använde inom familjedomänen på basis av självrapporteringen.

Tabell 3. Informanternas språkval inom familjedomänen på basis av självrapportering år 2012.

\begin{tabular}{|l|l|l|l|l|}
\hline Informant & $\begin{array}{l}\text { Språkval med } \\
\text { fadern }\end{array}$ & $\begin{array}{l}\text { Språkval med } \\
\text { modern }\end{array}$ & $\begin{array}{l}\text { Språkval med } \\
\text { syskonen }\end{array}$ & $\begin{array}{l}\text { Språkval med } \\
\text { släktingar }\end{array}$ \\
\hline 1 & finska & finska/norska & norska/finska & finska \\
\hline 2 & finska & norska/finska & norska & finska \\
\hline 3 & norska/finska & norska/finska & norska & norska/finska \\
\hline 4 & finska & finska & norska & finska \\
\hline 5 & finska & finska & norska & finska \\
\hline 6 & norska/finska & norska & norska & norska/finska \\
\hline
\end{tabular}


Inom hemdomänen har det skett en del förändringar i språkvalet under de gångna åtta åren. För det första talade syskonen sinsemellan enbart norska utom informant 1 , som använde både norska och finska med sin äldre syster som inte deltog i undersökningen. Även tidigare forskning visar att syskonen sinsemellan ofta använder majoritetsspråket (Janulf, 1998; Niiranen, 2008; Tuomela, 2001). För det andra talade två ungdomar norska även med sin far. För det tredje skedde det förändringar i språkvalet med modern. Vid tidpunkten för enkäten talade informant 1 båda språken med sin mor medan hon tidigare talade bara finska. Hos informanterna 2 och 3 var det dominerande språket med modern norska. Intressant är att ett syskonpar (informanterna 4 och 5) talade enbart finska med modern när de åtta år tidigare vid intervjutillfället använde båda språken. Trots att familjen till syskonparet hade bott i Norge i över 15 år, hade familjen täta kontakter med släktingar i Finland. Informant 5 skulle också göra sin militärtjänst i Finland. Ungdomarna hade förstått att de hade stor nytta av att kunna finska vilket möjligen bidragit till att de använde båda språken (jfr Caldas, 2006). Med de finsktalande släktingarna i Finland talade alla informanterna enbart finska. Två informanter (3 och 6) hade släktingar i Norge och det dominerande språket med dessa var norska.

\subsection{Språkvalet inom fritidsdomänen (inkl. vänner)}

I intervjun tillfrågades modern och barnet om barnets fritidsaktiviteter och vilka språk som användes i detta sammanhang. Modern och barnet ombads även berätta i vilken grad de hade norska och finska bekanta i Norge och de fick ange språkvalet i sin samvaro med finsktalande vänner. Tabell 4 visar språkval inom fritidsdomänen på basis av intervjun.

Tabell 4. Språkval inom fritidsdomänen (inkl. vänner) på basis av intervju år 2004. Språket som barnet använder mest har nämnts först.

\begin{tabular}{|l|l|l|l|l|}
\hline Informant & $\begin{array}{l}\text { Språkval } \\
\text { med vänner }\end{array}$ & $\begin{array}{l}\text { Språkval med } \\
\text { finska vänner i } \\
\text { Norge och Finland }\end{array}$ & $\begin{array}{l}\text { Språkval i } \\
\text { fritidsaktiviteter } \\
\text { utanför skolan }\end{array}$ & $\begin{array}{l}\text { Språkval med } \\
\text { föräldrarnas } \\
\text { finsktalande vänner }\end{array}$ \\
\hline 1 & norska & finska & norska & finska \\
\hline 2 & norska & finska & norska & finska \\
\hline 3 & norska & finska & norska & finska \\
\hline 4 & norska & finska & norska & finska \\
\hline 5 & norska & finska & norska & finska \\
\hline 6 & norska & norska/finska/eng & norska & norska/finska \\
\hline
\end{tabular}


På fritiden umgicks barnen i regel med norsktalande vänner utanför skolan (se tabell 4). När det gäller fritidsaktiviteterna hade de flesta barn som deltog i aktiviteterna norska som S1 och därför var det naturligt att tala norska. Familjerna till barn som ingick i denna studie bodde i bostadsområden där det fanns få barn som hade ett annat $S 1$ än norska. Även alla tränare eller ungdomsledare var norsktalande. Informanterna 1, 4 och 5 hade under en period finsktalande klasskamrater i lågstadieskolan och också då talade barnen norska med dem då de inte ville skilja sig från andra elever. Vid intervjutillfället gick bara informant 1 i finsk lördagsskola (Suomikoulu), där informanten hade regelbunden kontakt med andra finsktalande ungdomar i samma ålder. Det dominerande språket där var finska.

Alla familjer i undersökningen hade kontakt med ett par andra finsktalande barnfamiljer. De träffades mindre än en gång i månaden och barnen, förutom informant 6 , talade finska med varandra. Informant 6 talade nästan enbart norska både inom hemdomänen och fritidsdomänen p.g.a. svaga kunskaper i finska. För övrigt deltog dessa familjer sällan i organiserade finskspråkiga aktiviteter på den tiden då intervjun genomfördes. Tidigare hade alla barnen deltagit i en finskspråkig lekklubb där familjerna och barnen kunde träffa andra finskatalande.

Enligt självrapporteringen åtta år efter intervjun var ungdomarna intresserade av många olika aktiviteter. På fritiden sysslade de bl.a. med friidrott, läsning, konst och dataspel. Majoriteten av deras vänner inom fritidsaktiviteterna var infödda norska ungdomar, men några informanter umgicks också med ungdomar som hade invandrarbakgrund. Ingen hade finska kamrater inom fritidsaktiviteterna. Tränarna och de andra vuxna inom fritidsaktiviteterna var norsktalande. Hobbyverksamheten gick helt och hållet på norska.
Självrapporteringen visar att norskan hade blivit ett allt mer dominerande språk inom fritidsdomänen (se tabell 5). Det framgick av svaren att ungdomarna hade få finska vänner i samma ålder i Norge och Finland. Informanterna träffade sina finsktalande vänner endast ett par gånger om året. Då använde de i regel både finska och norska beroende på samtalsämnet. Informant 2 hade en finskspråkig studiekamrat och talade enbart finska med henne. Informant 6 talade även engelska med sina finsktalande kamrater p.g.a. sina svaga språkkunskaper i finska. De finska familjernas bekantskapskrets omfattade både finska och norska familjer. Två familjer i intervjun sade sig umgås mest med finländare (föräldrarna till informanterna 2, 4 och 5) medan två umgicks mest med norrmän (föräldrarna till informanterna 1, 3 och 6). Familjerna som umgicks mest med norrmän hade bott $\mathrm{i}$ Norge i över 20 år vid intervjutillfället. När ungdomarna umgicks med föräldrarnas finska vänner talade de det språk som de finska vännerna talade med dem.

Samtliga familjer i undersökningen hade alltså finsktalande vänner i sitt sociala nätverk, men kontakterna var sporadiska. Detta beror på att det bodde relativt få finländare i närmiljön och de finsktalande vuxna i undersökningen deltog sällan i organiserade aktiviteter på finska. En av orsakerna är att finska vuxna invandrare har relativt lätt att anpassa sig till det norska samhället och inte upplever något större avstånd till den norska kulturen. Dessutom kommer finska invandrare, ofta med högre utbildning, från ett land där svenska är landets andra nationalspråk. Alla har (i princip) vissa kunskaper i svenska. Det relativt begränsade intresset för verksamhetsformer där man skulle kunna träffa andra finskspråkiga tycks vara något som skiljer den finska minoritetsgruppen från andra motsvarande grupper i Norge. Detta framgår tydligt när man jämför resultaten i Kulbrandstad (1997) 
och Svendsen (2005). Informanterna i dessa studier tenderade att delta i evenemang där de kunde umgås på sitt $S 1$. De hade möjlighet att göra det då det fanns flera med samma $S 1$ i närliggande bostadsområden. De finsknorska ungdomarna i Hjulstad Junttilas och Anderssons (1994) samt Niiranens (2008) undersökningar däremot deltog oftast i aktiviteter där de måste använda majoritetsspråket på grund av få finsktalande i närmiljön. Även föreliggande studie visar ett liknande språkanvändningsmönster inom fritidsdomänen hos ungdomarna i Osloområdet.

Tabell 5. Språkval inom fritidsdomänen (inkl. vänner) på basis av enkät år 2012.

\begin{tabular}{|l|l|l|l|l|}
\hline Informant & $\begin{array}{l}\text { Språkval } \\
\text { med vänner }\end{array}$ & $\begin{array}{l}\text { Språkval med } \\
\text { finska vänner i } \\
\text { Norge och Finland }\end{array}$ & $\begin{array}{l}\text { Språkval inom } \\
\text { fritidsaktiviteterna } \\
\text { utanför skolan }\end{array}$ & $\begin{array}{l}\text { Spräkval med } \\
\text { föräldrarnas } \\
\text { finsktalande vänner }\end{array}$ \\
\hline 1 & norska & finska & norska & finska \\
\hline 2 & norska & finska/norska & norska & finska \\
\hline 3 & norska & finska & norska & finska/norska \\
\hline 4 & norska & norska/finska & norska & finska/norska \\
\hline 5 & norska & finska & norska & finska/norska \\
\hline 6 & norska & norska/finska/eng & norska & norska/finska \\
\hline
\end{tabular}

\subsection{Språkval och massmediebruk}

Ett av syftena med min undersökning var att se vilket språk som används i massmediebruket. Norsk mediebarometer kartlägger årligen norrmännens medieanvändning och undersökningen täcker alla ungdomar oavsett nationalitet. Norsk mediebarometer (2009) gav även information om invandrarungdomarnas medieanvändning. Kartläggningen visar att dessa såg mycket på TV och använde Internet medan de sällan läste tryckta tidningar och veckotidningar på papper. Många ungdomar såg påTV-program från sitt eget hemland och besökte nätsidor på sitt S1. De ungdomar som bott längst i Norge såg mest på norska TVkanaler.
Vad informanternas massmediekonsumtion beträffar, har de besvarat olika frågor i intervjun och i enkäten. Tabell 6 visar informanternas språkval vid intervjutillfället.

Informanterna 1, 3 och 6 (se tabell 6) är födda i Norge men barnkulturen levererades till dem på båda språken. Kvällssagor och andra böcker höglästes för dem på finska, men de blev tidigt exponerade för norsk barn-TV. Barnen fick även möjligheter att se på finskspråkiga DVD:er. Dessutom prenumererade föräldrarna ofta på finskspråkiga serietidningar. Barnen lyssnade också på finsk musik och spelade dataspel på finska. Av tabell 6 framgår att barnen använde såväl finska som norska efter sin språkliga preferens och sina språkkunskaper. Informanternas medievanor i enkäten framgår av tabell 7 . 
Tabell 6. Språkval och massmediebruk på basis av intervju 2004.

\begin{tabular}{|l|l|l|l|l|l|l|l|}
\hline Informant & Böcker & Serietidningar & Dataspel & Vykort & TV & DVD & Cd \\
\hline 1 & no, $\mathrm{fi}$ & $\mathrm{fi}$ & $\mathrm{no}, \mathrm{fi}$ & $\mathrm{fi}$ & $\mathrm{no}$ & $\mathrm{no}, \mathrm{fi}$ & $\mathrm{no}, \mathrm{fi}$ \\
\hline 2 & $\mathrm{no}, \mathrm{fi}$ & $\mathrm{fi}$ & $\mathrm{no}, \mathrm{fi}$ & $\mathrm{no}$ & $\mathrm{no}$ & $\mathrm{no}, \mathrm{fi}$ & $\mathrm{no}, \mathrm{fi}$ \\
\hline 3 & $\mathrm{no}, \mathrm{fi}$ & $\mathrm{no}$ & $\mathrm{no}, \mathrm{fi}$ & $\mathrm{no}, \mathrm{fi}$ & $\mathrm{no}$ & $\mathrm{no}, \mathrm{fi}$ & $\mathrm{no}, \mathrm{fi}$ \\
\hline 4 & $\mathrm{no}, \mathrm{fi}$ & $\mathrm{fi}$ & $\mathrm{no}$ & $\mathrm{fi}$ & $\mathrm{no}$ & $\mathrm{no}$ & $\mathrm{no}, \mathrm{fi}$ \\
\hline 5 & $\mathrm{no}, \mathrm{fi}$ & $\mathrm{fi}$ & $\mathrm{no}$ & $\mathrm{fi}$ & no & no & no \\
\hline 6 & $\mathrm{no}, \mathrm{fi}$ & no & no, $\mathrm{fi}$ & no & no & no, fi & no \\
\hline
\end{tabular}

Tabell 7. Språkval och massmediebruk baserat i självrapportering 2012.

\begin{tabular}{|l|l|l|l|l|l|l|l|}
\hline Informant & Böcker & $\begin{array}{l}\text { Veckotidn. } \\
\text { och } \\
\text { tidningar }\end{array}$ & $\begin{array}{l}\text { Internet \& } \\
\text { sociala medier } \\
\text { inkl. e-post }\end{array}$ & SMS & $\begin{array}{l}\text { Skrivande } \\
\text { privat } \\
\text { hemma }\end{array}$ & $\begin{array}{l}\text { TV och } \\
\text { DVD }\end{array}$ & Radio \\
\hline 1 & no (eng) & no,fi & no & no,fi & $\mathrm{fi}$ & no & no \\
\hline 2 & no,fi & no & no,fi & no & no & no,fi & no \\
\hline 3 & no (eng) & no,fi & no & no & no & no & no,fi \\
\hline 4 & no (eng) & no,fi & no & no,fi & $\mathrm{fi}$ & no & no,fi \\
\hline 5 & (eng) & no & no,fi & no,fi & $\mathrm{fi}$ & no,fi & no \\
\hline 6 & no (eng) & no & no & no & no & no & no \\
\hline
\end{tabular}

Vid tidpunkten för enkäten konsumerade en övervägande del av ungdomarna medier oftare på norska än på finska (se tabell 7). De skilda medierna utnyttjades också i olika omfattning. Informanterna 1 och 2 hade läsning som hobby. Den ena läste både på norska och finska medan den andra läste på norska. En informant läste böcker på engelska, men inte på norska eller finska och tre andra informanter uppgav att de sällan läste. I enkäten angav flertalet av ungdomarna att de läste norska tidningar och veckotidningar dagligen, medan de ytterst sällan eller aldrig läste dem på finska. Informanterna 1 och 4 berättade att de brukade läsa finska veckotidningar och tidningar i Finland om sommaren. Intressant är att alla informanterna uppgav i intervjun att de tyckte om att läsa böcker medan det enligt självrapporteringen var bara två informanter som hade läsning som hobby. Informanterna i Kulbrandstads (1997) studie visade en liknande tendens. De yngsta barnen (årskurs 3) i undersökningen läste mycket medan de något äldre barnen (årskurs 8) läste sällan.

Bruket av Internet och sociala medier var populärt bland ungdomarna och alla använde dem dagligen. De flesta besökte webbsidor på norska men informanterna 2 och 5 besökte även finska webbsidor. Sociala medier använde ungdomarna i allmänhet på norska. Det privata skrivandet omfattade meddelanden hemma, SMS och mejl. Informanterna 1, 4 och 5 brukade skriva i synnerhet meddelanden och SMS på finska. Att informanterna använde finska kan kanske förklaras med att man ofta skriver snabbt, nonchalant och 
med korta, ofullständiga meningar i det informella språket. I snabba medier som SMS behöver man inte behärska det finska skriftspråkets alla finesser fullständigt för att skriva sådana meddelanden. Ungdomarna brukade dagligen titta på norska TV-program medan konsumtionen av finskspråkiga TV-program varierade alltifrån några gånger i veckan till att de aldrig såg program på finska. Endast informanterna 2 och 5 såg på finska program via Internet även om den moderna teknologin gör det mycket enkelt. Det varierar betydligt, hur ofta ungdomarna i undersökningen lyssnade på radio. Några hörde på radiosändningar jämt, medan andra aldrig lyssnade på radioprogram. Informanterna 3 och 4 lyssnade på finska radioprogram från Finland. Intresset för finskspråkiga massmedier verkade vara sporadiskt hos informanterna i min undersökning medan informanterna i Niiranens (2008) studie tittade mycket mer på finska TV-program. En förklaring till detta kan vara att de sistnämnda ofta reste över gränsen till Finland, där de också fick möjlighet att följa med det finska TV-utbudet och därmed i högre grad kände till programmen.

\section{SAMMANFATTANDE DISKUSSION}

Syftet med studien har varit att undersöka utvecklingen i språkanvändning och språkval bland finsk-norska ungdomar i Osloområdet. Sex barn samt deras mödrar har intervjuats och åtta år senare har samma ungdomar fyllt i en enkät om sitt språkbruk i tre domäner: hemmiljön, fritidsmiljön och massmediebruket. I denna artikel redovisas vilka förändringar som skett i språkbruket inom de tre domänerna. Syftet har också varit att belysa faktorer som kan tänkas ha inverkan på språkanvändningen hos ungdomarna. Språkvalet bland ungdomarna i Osloområdet har sedan jämförts med tidigare forskningsresultat i stu- dier om finsktalande ungdomar i Nordnorge och i Sverige (Hjulstad Junttila \& Andersson, 1994; Janulf, 1998; Komeros, 2009; Niiranen, 2008; Tuomela, 2001) samt andra minoritetsspråkiga barn och ungdomar i Norge (Kulbrandstad, 1997; Svendsen, 2005) och Sverige (Namei, 2012; Straszer, 2011).

Informanternas språkval har förändrats i viss mån under de åtta år som gått mellan de två materialinsamlingstillfällena. Det har skett en del förändringar i språkvalet inom hemdomänen. För det första talade syskonen sinsemellan oftast norska vid det senare tillfället, för det andra talade några ungdomar även norska med sin far då de tidigare talade finska och för det tredje talade några ungdomar enbart finska med sin mor då de förr använde båda språken. Det visar att det inte enbart har skett en entydig förnorskning. Inom fritidsdomänen har det inte skett betydliga förändringar. Norskan var det dominerande språket vid intervjutillfället och dominerade även vid tidpunkten för enkäten. När det gäller språkvalet i massmediebruket kan man dra den slutsatsen att en övervägande del av ungdomarna konsumerade medier oftare på norska än på finska.

Resultaten i tidigare studier fastslår att minoritetsspråkliga ungdomar använder både sitt S1 och S2 inom olika domäner avhängigt av samtalspartner, situation och samtalsämne men mest används S1 inom hemdomänen (Hjulstad Junttila \& Andersson, 1994; Janulf, 1998; Niiranen, 200; Tuomela, 2001). Resultaten i denna studie avviker i viss mån från Janulfs (1998) och Tuomelas (2001) studier. Trots att båda föräldrarna är finsktalande, är de finsk-norska ungdomarnas klart dominerande språk norska, även inom hemdomänen. Om båda föräldrarna är minoritetsspråkstalare av samma språk tenderar det att stärka språkbevarandet (Boyd m.fl., 1994; Rydenvald, 2014) men studiens resultat pekar inte på det. 
För att kunna beskriva enskilda faktorers inverkan på språkanvändningen borde en betydligt större kvantitativ studie göras men utifrån tidigare forskning vill jag reflektera över en del faktorer (se närmare kapitel 3). Språkvalet inom olika domäner påverkas av de personer som är involverade. Ungdomarna är vana vid att välja ett språk i anknytning till en person. De talar oftast finska med fadern, finska eller norska med modern och norska med syskonen. I kontakt med släktingar och vänner i Finland, är de andras språkkunskaper avgörande och oftast är situationen sådan att informanten måste tala finska. Utanför familjen är det naturligast att tala majoritetsspråket, dvs. norska med vänner, skolkamrater, lärare och tränare. Liknande resultat har framkommit i tidigare studier (Niiranen, 2008; Straszer, 2011; Tuomela, 2001).

Informanternas vistelsetid i Norge kan också tänkas ha inverkan på språkvalet. Ju längre de har bott i Norge, desto mer använder de norska inom hemdomänen och i mediebruket. Min undersökning visar i likhet med Kulbrandstads (1997) undersökning om iransk-norska och vietnamesisk-norska elever att språkvalet kan hänga ihop med vistelsetiden i värdlandet. Vad gäller bruket av medier, tycks även språklig preferens spela en roll vid språkvalet (Caldas, 2006).

Språkvalet är ofta förbundet med den etniska och språkliga identiteten (Aalto, 2015; Allardt Ljungren, 2008; Henning-Lindblom, 2012; Liebkind, 2010). Många tvåspråkiga är medvetna om att de i någon mån har en tvåkulturell identitet (Baker, 2007; HenningLindblom, 2012; Straszer, 2011). En individ kan identifiera sig med båda grupperna eller välja att identifiera sig starkare med den ena eller den andra gruppen (Baier, 2007; se också Allardt Ljunggren, 2008). I intervjuerna frågades informanterna och deras mödrar om barnets etniska identitet. Alla mödrarna ansåg att barnen identifierade sig främst som finländare medan barnen själva hade delade meningar. I barndomen är föräldrarna viktiga förebilder för sina barn och barnen vill vara som mor och far (Benjamin, 2014). I tonåren är många osäkra på sin identitet och grupptillhörighet och vill helst vara så lika sina (norska) vänner som möjligt och identifiera sig som norrmän (se också Caldas, 2006). Enligt självrapportering kände sig informanterna delaktiga i båda kulturerna och de ansåg sig ha dubbel, finsk-norsk identitet. Vad gäller informanternas språkliga identitet, definierade sig fem av sex som tvåspråkiga. De kände mest tillhörighet till det norska språket men var glada att kunna finska. Resultatet skiljer sig från Aaltos (2015) studie där de finskspråkiga ungdomarna i Bryssel betraktade sig som enspråkigt finska. Intressant i min undersökning är att samtliga informanter ansåg att norskan och engelskan var viktigare språk för dem än finskan. Alla utom en var dock positiva till tanken att tala finska med sina barn (jfr Doyle, 2013; Rydenvald, 2014). Den informant som inte kunde tänka sig det har svaga språkfärdigheter i finska. Ungdomarnas språkliga attityder verkar inte ha något direkt samband med språkvalet. Attityderna kunde vara positiva till båda språken, men likväl använde de mest majoritetsspråket.

Informanternas sociala nätverk består nästan enbart av norrmän och därmed är möjligheterna att använda finska få. Finländarna i Osloområdet består av drygt 2000 personer och de bor spridda runt om i området. Detta leder till att bruket av majoritetsspråket underlättas av bosättningsmönstret medan bruket av S2 försvårar förstaspråksanvändningen (jfr Kovács, 2004; se också Namei, 2012; Niiranen, 2008). Ungdomarna deltog även passivt i finska evenemang, särskilt när vistelsetiden i Norge blev längre (se också Heikkola, 2005). Det institutionella stödet (språkets ställning inom olika sociala sektorer som undervisning, massmedia och kultur) och språk- 
ets status har stor betydelse i språkval och språkbevarande (Fredriksen, 1997; Romaine, 1995). Resultaten i tidigare studier tyder på att ungdomar som har fått hemspråksundervisning använder minoritetsspråket i större utsträckning än de som inte fått det (Aalto, 2015; Janulf, 1998; Rydenvald, 2014; Tuomela, 2001). På grund av att antalet informanter i min undersökning är litet, kan jag inte dra några långtgående slutsatser om detta.

Språkvalet avspeglar på många sätt det som sker i den kringliggande omgivningen. Ungdomarna har haft begränsade möjligheter att få undervisning i och på finska och masskulturen tillhandahålls nästan enbart på norska. Detta ger dem inte så många tillfällen att använda finska utanför hemmet. Ungdomarnas uppväxtmiljö i Osloområdet bär således en svag prägel av ett genuint tvåspråkigt samhälle och det norska språket är starkt representerat i ungdomarnas vardag. Trots detta har de flesta ungdomar lyckats bevara sitt förstaspråk och använder finska aktivt i naturliga kommunikationssituationer i sin omgivning. Ett undantag utgörs av en ungdom som har svaga kunskaper i finska och har successivt övergett sitt $\mathrm{S} 1$ till förmån för S2 och på så sätt blivit mer eller mindre enspråkig. Språkanvändningen har stor betydelse för språkfärdigheterna. För framtida studier vore det intressant att närmare undersöka ungdomarnas språkfärdigheter i finska och norska och relatera resultaten till deras språkval. Det vore även intressant att studera varför en del familjer har lyckats fostra sina barn till aktivt tvåspråkiga medan andra har haft mindre framgång.

Det longitudinella perspektivet, d.v.s. studiens datainsamling vid två olika tillfällen har gjort det möjligt att studera utvecklingen i språkanvändningsmönstret under de åtta år som gått mellan de två materialinsamlingstillfällena. Eftersom denna studie baserar sig på ett begränsat antal informanter, kan den dock inte ge underlag för några generella slutsatser om språkval bland finsk-norska ungdomar i Osloområdet. Dessutom är fyra av informanterna syskon, något som är en ytterligare begränsning. För att få djupare kunskap om språkval borde materialet utvidgas och göras till en betydligt större kvantitativ studie. Därmed vore det möjligt att ge en pålitligare och mera djupgående information om språkval och de faktorer som påverkar språkvalet. Studien har några metodologiska problem. En brist i materialsamlingen är att intervjuerna inte inspelades eftersom fokus var på innehåll och inte på språkliga former. Det är också svårt att bedöma hur väl självrapporterat språkbruk överensstämmer med det faktiska språkbruket. Detta gäller både intervjuer och den information som man får genom en skriftlig enkät.

\section{LITTERATUR}

Aalto, M. (2015). Suomenkielisenä Brysselissä varhaisnuorten kielellinen identiteetti. Puhe ja kieli, 35, 3-22.

Anttonen, M. (2008). Norja. I: K. Björklund \& O. Koivukangas (red.), Suomalaiset Euroopassa. Suomalaisen siirtolaisuuden historia, osa 6, (s. 25-59). Siirtolaisuusinstituutti. Turku.

Auer, P. \& Wei, L. (eds.) (2007). Handbook of multilingualism and multilingual communication. Berlin: Mouton de Gruyter.

Baier, M. (2007). Sprachliche Situation der in Deutschland lebenden Finnen unter besonderer Berücksichtigung der Rezession der Muttersparche. Diss. Acta Universitatis Tamperensis 1249. University of Tampere.

Baker, C. (2001). Foundations of bilingual education and bilingualism. ( $3^{\text {rd }}$ edition). Bilingual Education and Bilingualism 54. Clevedon: Multilingual Matters.

Baker, C. (2007). Parents' and teachers's guide to bilingualism. (3rd edition). Clevedon: Multilingual Matters.

Barron-Hauwaert, S. (2011). Bilingual siblings: Language use in families. Bristol: Multilingul Matters. 
Benjamin, S. (2014). Kulttuuri-identiteetti Merkitys kehitykselle ja kotoutumiselle. I: M. Laine (red.), Kulttuuri-identiteetti \& kasvatus. Kulttuuriperintökasvatus kotouttamisen tukena. Suomen kulttuuriperintötutkimuksen seuran julkaisuja 8, (s. 56-105). Tillgänglig 2.6.2015 i http://www.kulttuuriakaikille.fi/doc/ monikulttuurisuus_kansio/Kulttuuri-identiteetti _ja_kasvatus.pdf.

Berglund, R. (2008). Ett barns interaktion på två språk - En studie i språkval och kodväxling. Diss. Acta Universitas Wasaensia 190. Vasa universitet. Institutionen för nordiska språk.

Boyd, S. (1985). Language survival: A study of language contact, language shift and language choice in Sweden. Diss. Gothenburg Monographs in Linguistics 6. Göteborgs universitet. Institutionen för lingvistisk.

Boyd, S., Holmen, A. \& Jørgensen, J.N. (red.) (1994). Sprogbrug og sprogvalg blandt indvandrere i Norden. Bind 2. Temaartikler. Københavnerstudier i tosprogethet bind 23. Köbenhavn: Danmarks lærerhøjskole.

Caldas, S. (2006). Raising bilingual-biliterate children in monolingual cultures. Clevedon: Multilingual Matters.

De Houwer, A. (2007). Parental language input patterns and children's bilingual use. Applied Psycholinguistics, 28, 411-424.

Doyle, C. (2013). To make the root stronger: Language policies and experiences of successful multilingual intermarried families with adolescent children in Tallinn. I: M. Schwartz \& A.Verschik (eds.), Successful Family Language Policy, (s. 145-175). New York: Springer.

Dörnyei, Z \& Taguchi,T. (2010). Questionnaires in second language research. Construction, administration, and processing. ( $2^{\text {nd }}$ edition). New York: Routledge.

Finske innvandrere i Norge. Statistikk Sentralbyrå. Tillgänglig 22.8.2016 i https://www.ssb.no/ innvbef.

Fogle, L.W. (2013). Family language policy from children's point of view: Bilingualism in place and time. I: M. Schwartz \& A.Verschik (eds.), Successful Family Language Policy, (s. 177-200). New York: Springer.

Forsman, L. (2015). Language shift in Gammalsvenskby: A Nexus analysis of the shift to Ukrainian in a traditionally Swedish-speaking com- munity. Journal of Sociolinguistics, 19, 37-61. Tillgänglig 10.6.2016 i http://onlinelibrary. wiley.com/doi/10.1111/josl.12112/full

Fredriksen, C. (1997). Bevaring av minoritetsspråk - hvilke faktorer ser ut til å spille inn? NOA - Norsk som Andrespråk, 20, 36-50. Institutt for lingvistiske fag, universitetet i Oslo.

Grosjean, F. (1982). Life with two languages. An introduction to bilingualism. Cambridge, MA; London: Harvard University Press.

Györky-Ullholm, K. (2010). Same mother tongue - Different origins. Implications for language maintenance and shift among Hungarian immigrants and their children in Sweden. Dissertations in Bilingualism 20. Stockholm: Stockholms universitet.

Haglund, C. (2004). Flerspråkighet och identitet. I: K. Hyltenstam \& I. Lindberg (red.), Svenska som andraspräk - i forskning, undervisning och sambälle, (s. 359-387). Lund: Studentlitteratur.

Hall, S. (1999). Identiteetti. Suom. ja toim. M. Lehtonen ja J. Herkman. Tampere:Vastapaino. Heikkola, L.M. (2005). Kieli kansallisen identiteetin peilinä. Koodinvaibto ja murre oslonsuomalaisten ja -italialaisten kielessä. Pro gradu avhandling. Åbo Akademi. Tillgänglig 12.5.2015 i http://www.users.abo.fi/lheikkol/ Heikkola-MastersThesis.pdf.

Henning-Lindblom, A. (2012). Vem ärjag, vem är vi, vem är vem $i$ vairt land? Kontextens betydelse for gruppidentifikation och stereotypier bland svensk- och finskspråkiga i Finland och Sverige. Akademisk avhandling. Statsvetenskapliga fakulteten vid Helsingfors universitet. SSKH skrifter 34 .

Iskanius, S. (2006). Venäjänkielisten maahanmuuttajaopiskelijoiden kieli-identiteetti. Dissertation. Jyväskylä Studies in Humanities 51. University of Jyväskylä. Tillgänglig 20.11.2015 i https://jyx.jyu.fi/dspace/bitstream/ handle/123456789/13433/9513925234. pdf ? sequence $=1$.

Janulf, P. (1998). Kommer finskan i Sverige att överleva? En studie av språkkunskaper och språkanvändning hos andragenerationens sverigefinnar i Botkyrka och hos finlandsvenskar $i$ Abo. Acta Universitatis Stockholmensis. Studia Fennica Stockholmiensia 7. Stockholm: Almqvist $\&$ Wiksell International. 
Junttila, J. Hjulstad \& Andersson, P. (1994). Språkbruk hos finnar i Göteborg og Finnmark. I: S. Boyd, A. Holmen \& J.N. Jørgensen (red.), Sprogbrugogsprogualgblandtindvandrere iNorden. Bind 22, (s. 55-101). Köbenhavn: Danmarks lærerhøjskole.

Komeros, A. (2009). Det flerspråklige Sør-Varanger. Masteroppgave i finske språk. Institutt for språkvitenskap. Universitetet i Tromsø. Tillgänglig 28.7.2016 i http://munin.uit.no/ bitstream/handle/10037/1931/thesis.pdf

Kopeliovich, S. (2013). Happylingual: A family project for enhancing and balancing multilingual development. I: M. Schwartz \& A.Verschik (eds.), Successful family language policy, (s. 249275). New York: Springer.

Kovács, M. (2004). Australiansuomalaiset kielenvaihdon kynnyksellä. Virittäjä, 108, 200-223.

Kulbrandstad, L. A. (1997). Språkportretter. Studier av tolv minoritetselevers språkbruksmønstre, språkholdninger og språkferdigheter. Vallset: Oplandske Bokforlag.

Kvale, S. \& Brinkmann, S. (2009). Det kvalitative forskningsintervju. (2.utg.). Oslo: Gyldendal akademisk.

Lainio, J. (2006). Barnen kan bli tvåspråkiga vuxna. Rapporter från Finskt språk- och kulturcentrum, FinSKC4. Mälardalens högskola. Tillgänglig 15.6.2015 i http://www.sverigefinne. nu/julkaisut/Kaksikielisyys2006.pdf.

Lanza, E. \& Svendsen, B.A. (2007). ”Tell me who your friends are and I might be able to tell you which languages you speak". International Journal of Bilingualism, 11, 275-300.

Lanza, E. 2007. Multilingualism and the family. I: P. Auer \& L.Wei (eds.), Handbook of Multilingual and Multilingual Communication, (s. 45-66). New York: Mouton de Gruyter.

Liebkind, K. (2010). Social psychology. I: J. Fishman \& O. Garcia (eds.), Handbook of language and ethnic identity. ( $2^{\text {nd }}$ edition). Volume I. Disciplinary and Regional Perspectives, (s. 18-31). New York: Oxford University Press.

Lindgren, A-R., Eskeland, T. \& Norman, M. (2003). Osima ja Baskabusk - monet suomet Norjassa? I: H. Jönsson-Korhola \& A-R.Lindgren (red.), Monena Suomi maailmalla: Suomalaisperäisiä kielivähemmistöjä, (s. 193-208). Helsinki: SKS.

Ljunggren, B. Allardt (2008). Aland som språksambälle. Språk och språkliga attityder på Åland ur ett ungdomsperspektiv. Dissertations in Bilingualism 16. Centrum för tvåspråkighetsforskning. Stockholms universitet

Milroy, L. \& Gordon, M. (2003). Sociolinguistics: Method and Interpretation. $2^{\text {nd }}$ edition. Malden, Mass: Blackwell Publishing.

Mæhlum, B. (2007). Konfrontasjoner når språk møtes. Oslo: Novus Forlag.

Namei, S. (2012). Iranians in Sweden: A Study of Language Maintenance and Shift. Skrifter utgivna av Institutionen för nordisk a språk vid Uppsala universitet 86. Uppsala: Uppsala universitet.

Niemi, E. (2010). Kvenene - Nord-Norges finner. En historisk oversikt. I: A.B. Lund \& B.B. Moen (red.). Nasjonale minoriteter i det flerkulturelle Norge, (s. 32-52). Tapir Akademisk Forlag. Trondheim.

Niiranen, L. (2008). Effects of Learning Contexts of Verbs. Lexical and Inflectional Knowledge of verbs among Pupils learning Finnish in Northern Norway. Diss. University of Tromsø.

Niiranen, L. (2011). Finsk som andrespråk i norsk skolefagets historie og dagens utfordringer. NOA - norsk som andrespråk, 1, 59-85.

Norsk mediebarometer 2009. Statistisk sentralbyrå. Tillgänglig 12.12.2012 i https://www.ssb. no/kultur-og-fritid/artikler-og publikasjoner /_attachment/63580?_ts=1369c019478.

Otterup, T. (2005). "Jagkänner mej begåvad bara". Om flersprakighet och identitetskonstruktion bland ungdomar $i$ ett multietniskt forrortsomrade. Göteborgstudier i nordisk språkvetenskap 2. Insitutionen för svenska språket. Göteborgs universitet.

Palviainen, Å., Lehtonen, J. \& Valli, T. (2012). Formulerande av familjespråkpolicy - en gemensam, komplex och ständigt pågående process. Tillgänglig 1.7.2015 i https://jyx.jyu.fi/dspace/ bitstream/handle/123456789/42770/ palviainenlehtonenvalli.pdf ?sequence $=1$.

Pavlenko, A. (2005). Emotions and Multilingualism. Cambridge: Cambridge University Press.

Romaine, S. (1995). Bilingualism. $2^{\text {nd }}$ edition. Oxford: Blackwell Publishing.

Rydenvald, M. (2014). "eftersom jag har två språk" Språkbruk bland svensktalande ungdomar i Europa. ROSA nr.19. Licentiatavhandling. Göteborgsuniversitet. Tillgänglig2.12.2015i https:// gupea.ub.gu.se/bitstream/2077/35684/1/ gupea_2077_35684_1.pdf. 
Spolsky, B. (2009). Language Management. Cambridge: Cambridge University Press.

Straszer, B. (2011). "Ungerska för rötternas skull": Spräkval och identitet bland andragenerationens ungrare i Sverige och Finland. Acta Universitatis Upsaliensis. Studia Uralica Upsaliensia 38. Uppsala universitet.

Sundman, M. (1999). Barnet, skolan och tvåspräkigheten. Helsingfors: Yliopistopaino.

Svendsen, B.A. (2005). Sa lenge vi forstår hverandre. Språkvalg, flerspråklige ferdigheter og språklige sosialisering hos norsk-filippinske barn i Oslo. Doktorsavhandling. Acta humaniora nr 216. Universitetet i Oslo.

Tandefelt, M. (1988). Mellan två språk. En fallstudie om språkbevarande og språkbyte i Finland.
Acta Universitatis Upsaliensis. Studia Multiethnica Upsaliensia 3. Akademisk avhandling. Uppsala universitet.

Tuomela, V. (2001). Tvåspråkig utveckling $i$ skolåldern. En jämförelse av sverigefinska elever $i$ tre undervisningsmodeller. Doktorsavhandling. Centrum för tvåspråkighetsforskning. Stockholms universitet.

Virta, E. (1994). Tvåspråkighet, tänkande och identitet. Studier av finska barn i Sverige och $i$ Finland. Del 1: Sammanfattning. Psykologiska institutionen. Stockholms universitet. Edsbruk: Akademi tryck.

Weckström, L. (2008). Representations of Finnishness in Sweden. Finnish Literature Society. Helsinki. Vantaa: Hansaprint Oy.

\section{LANGUAGE CHOICE AMONG FINNISH-NORWEGIAN YOUTH IN THE GREATER OSLO AREA}

Kristiina Lieri, University of Turku

The aim of the study is to examine language choice among six Finnish-Norwegian youth aged 17 to 22 years within three domains: home, free time and mass media and how this has changed during the eight years' time. Also examined are the factors that may influence language choice. The material consists of interviews and questionnaire. The study has been conducted with a sociolinguistic approach.

The results show that Norwegian is the predominant language among the subjects in all domains, except at home where the informants also speak Finnish. During the study, some changes in language choice, especially in home domain, have occurred. The main factors influencing the language choice are the subject's social network and a change in language identity. The findings confirm that some adolescents show more bilingual activity than others.

Keywords: bilingualism, domain, Finnish, language choice, Norwegian 


\section{OSLON SEUDUN NORJANSUOMALAISTEN NUORTEN KIELIVALINTA}

Kristiina Lieri, Turun yliopisto

Tarkastelen artikkelissani kuuden Oslon seudulla asuvan 17-22-vuotiaan nuoren kielivalintaa suomen ja norjan kielen välillä kolmella domeenilla (koti, vapaa-aika ja tiedotusvälineet) ja miten se on muuttunut kahdeksan vuoden ajanjakson aikana. Lisäksi pohdin, mitkä tekijät mahdollisesti ovat vaikuttaneet kielivalintaan. Tutkimusmateriaali koostuu haastatteluista ja kyselykaavakkeesta. Tutkimuksella on sosiolingvistinen lähestymistapa.

Tulokset osoittavat, että norja on nuorten dominoiva kieli kaikilla domeeneilla, paitsi domeenilla koti, jossa informantit puhuvat myös suomea. Tutkimuksen aikana kielivalinnassa on tapahtunut joitakin muutoksia, erityisesti kotidomeenilla. Etenkin informanttien sosiaaliset verkostot ja kieli-identiteetin muutos näyttävät vaikuttavan kielivalintaan. Tulokset osoittavat myös, että jotkut nuoret ovat aktiivisemmin kaksikielisiä kuin toiset.

Avainsanat: domeeni, kaksikielisyys, kielivalinta, norja, suomi 